\title{
Evaluation of the Level of Vitamin D and Angiopoetic Factors in Preeclampsia
}

\section{Vitamini ve Anjiopoetik Faktörlerin Preeklampside Değerlendirilmesi}

\author{
Sükeynet Aydın ${ }^{1}$, Asuman Deveci Özkan², Hilal Uslu Yuvacı ${ }^{3}$, Fatıma Betül Tuncer ${ }^{4}$, Mehmet Akdoğan ${ }^{4}$ \\ ${ }^{1}$ Sakarya University, Institute of Health Science, Department of Medical Biochemistry, Sakarya, Turkey. \\ ${ }^{2}$ Sakarya University, Faculty of Medicine, Department of Medical Biology, Sakarya, Turkey. \\ ${ }^{3}$ Sakarya University, Faculty of Medicine, Department of Obstetrics and Gynecology, Sakarya, Turkey. \\ ${ }^{4}$ Sakarya University, Faculty of Medicine, Department of Medical Biochemistry, Sakarya, Turkey.
}

e-mail: sukunetaydin@gmail.com,deveci@sakarya.edu.tr, hilaly@sakarya.edu.tr, makdogan2009@gmail.com, ORCID: 0000-0003-2150-1376

ORCID: 0000-0002-3248-4279

ORCID: 0000-0001-8067-3165

ORCID: 0000-0002-4034-4188

ORCID: 0000-0003-0169-4588

*Sorumlu yazar/ Corresponding Author: Asuman Deveci Özkan

Gönderim Tarihi / Received: 17.12.2020

Kabul Tarihi / Accepted: 06.03.2021

DOI: $10.34087 /$ cbusbed. 841840

\section{$\ddot{\mathbf{O} z}$}

Giriş ve Amaç: Patogenezi halen tam olarak aydınlatılmamış bir gebelik komplikasyonu olan preeklampsi, gelişmiş ülkelerde maternal/fetal morbidite ve mortalitesi yüksek seyreden hastalıklar arasındadır. Literatürde D vitamini eksikliğinin gebe kadınlarda daha sık görüldüğü ve preeklampsili gebelerde D vitamini eksikliğinin değerlendirildiği çalışmaların çelişkili sonuçlara sahip olduğu görülmektedir. Bu çelişkiler göz önünde bulundurularak çalışmamızda preeklampsi ile komplike olmuş gebelerde maternal eksikliği/yetersizliğinde birçok rahatsızlı̆a sebep olan D Vitamini ve anjiopoetik faktörlerin düzeyinin değerlendirilmesi amaçlanmıştır.

Gereç ve Yöntemler: Çalışmaya Sakarya Üniversitesi Eğitim ve Araştırma Hastanesi (SEAH) Kadın Hastalıkları ve Doğum Polikliniği'ne başvuran 31 preeklampsi tanısı almış gebe ve 32 sağlıklı gebe dahil edilmiştir. Hasta ve kontrol grubundaki bireylerden alınan açlık kan numuneleri santrifüj edilip serum ve plazmalarına ayrılmıştır. Serum $25(\mathrm{OH})$ Vitamin D düzeyi CLIA yöntemiyle, TNF- $\alpha$ ve PIGF düzeyi ELISA yöntemiyle, PCT düzeyi ise ECLIA yöntemiyle ölçülmüştür.

Bulgular: Preeklamptik gebe grubunda 25(OH)Vitamin D ve PIGF düzeyi kontrol grubuna göre düşük $(\mathrm{p}<0,001)$, TNF- $\alpha$ ve PCT düzeyleri ise yüksek tespit edilmiştir $(p<0,001)$, $(p<0,05)$. TNF- $\alpha$ düzeyi ve AST, ALT değerleri arasında istatistiksel olarak anlamlı pozitif bir korelasyon bulunmuştur $(p=0,001)$. Ayrıca PCT düzeyi ve PLT sayısı arasında da anlamlı pozitif bir korelasyon ortaya konmuştur $(\mathrm{p}=0,000)$.

Sonuç: Çalışmamızın sonuçları preeklamptik gebelerde serum $25(\mathrm{OH})$ Vitamin D düzeylerinin sağlıklı gebelere göre düşük olduğunu ve bir inflamasyon belirteci olan TNF- $\alpha$ düzeylerinin de yüksek olduğunu göstermektedir.

Anahtar kelimeler: D Vitamini, Plasental Büyüme Faktörü, Preeklampsi, Prokalsitonin, Tümör Nekrozis Faktör.

\section{Abstract}

Objective: Preeclampsia (PE), a pregnancy complication whose pathogenesis is still not fully clarified. Studies in the literature evaluating vitamin D deficiency more frequently in women with PE have conflicting results. Considering these contradictions, we aimed to evaluate the level and predictable potential of Vitamin D and angiogenic factors causing many disorders in maternal deficiency/insufficiency in women with PE.

Materials and Methods: Thirty-one (31) women diagnosed with PE and thirty-two (32) healthy pregnant women were included in this study. Vitamin D levels were measured by the chemiluminescence immunoassay (CLIA) TNF$\alpha$ and PLGF levels by ELISA and PCT levels by electrochemiluminescence assay (ECLIA) method. ROC curves were created to determine the role of biochemical parameters in the prediction of PE. 
Results: Vitamin D and PLGF levels were found lower and TNF- $\alpha$ and PCT levels were found higher in the PE group compared to the control group. The area under the ROC was $0.814,0.7681,0.8201,0.9251$ for gestational week (GW), Vitamin D, TNF- $\alpha$ and PLGF, respectively.

Conclusion: Vitamin D, TNF-a, PLGF values are consistent with the literature and they could be important markers in the prediction of PE. Our data revealed that these markers, which are already routinely analyzed, do not require an additional cost and time. Thereby, women with PE could be identified and followed up closely.

Keywords: Preeclampsia, Placental Growth Factor, Procalcitonin, vitamin D, Tumor Necrosis Factor Alpha.

\section{Introduction \\ $\mathrm{PE}$ is a condition specific to human pregnancy due} to insufficient spiral-arterial remodeling caused by poor trophoblast invasion is based on the presence of abnormal placenta. Additionally, the clinical symptoms of PE are based on the combination of factors released from the placenta into the maternal circulation, in addition to the maternal response and sensitivity to these factors [1]. It has been reported that angiogenesis mechanism is damaged in PE and many pro- and anti-angiogenic proteins are produced in the placenta before PE occurs [2]. High levels of circulating anti-angiogenic factors cause maternal endothelial dysfunction, and it has been reported that these factors increase before the disease becomes clinically evident and correlate with the severity of PE [3]. A recent study has shown that the increase in the amount of placental anti-angiogenic factor soluble Fms-like tyrosine kinase-1 (sFlt-1) antagonizes vascular endothelial growth factor (VEGF) and placental growth factor (PLGF) and triggers endothelial dysfunction [4]. sFlt-1 is defined as an endogenous anti-angiogenic protein that acts by blocking VEGF and PLGF receptor binding sites and causing endothelial dysfunction [5]. Thus, it has been reported that PE occurs with the increase in circulation of anti-angiogenic factors (sFlt-1, sEng) that antagonize a number of angiogenic factors such as ischemia and abnormal placental location and PLGF [6].

Vitamin D is synthesized in tissues and given into the bloodstream and it is known as a steroid hormone because it affects other tissues in the body and this effect is regulated by the feedback mechanism [7]. Adequate vitamin D level during pregnancy is important to ensure maternal response to the calcium requirement of fetus and newborn [8]. It has been stated that vitamin D has a regulatory role in skeletal metabolism, calcium homeostasis and immune, nervous and cardiovascular systems [9]. Vitamin D deficiency is known to cause many health problems. It has been stated that vitamin D deficiency during pregnancy is associated with $\mathrm{PE}$, gestational diabetes and periodontal diseases [10]. A study showed that the relationship between high gestational hypertension incidence and low vitamin D concentration and vitamin D deficiency may be an independent risk factor for the development of PE [11].

Additionally, TNF- $\alpha$ is a pro-inflammatory cytokine with a wide range of biological activities including regulation of immune functions and inflammatory reaction process [12]. TNF- $\alpha$ and its receptors regulate many physiological functions in the body, including immune surveillance to combat microbial infections, immune reactions to induce cell death, for example, to eliminate cancer cells, or to pathological conditions such as allergies [13]. Studies have reported that cytokine balance is important in the regulation of pregnancy and cytokines are critical mediators of healthy pregnancy due to their ability of greatly alter cellular functions such as migration, cell-cell communication, proliferation and gene expression [14, 15]. Pro-inflammatory cytokine (TNF- $\alpha$, IL-6) levels increase and anti-inflammatory cytokine (IL- 4, IL 10) levels decrease in placenta and serum of pregnant women complicated with PE. In addition, studies show that there is a significant relationship between increased TNF- $\alpha$ level and the risk of developing PE $[2,16]$. In addition to these Procalcitonin (PCT) is an inflammation-related prohormone that has not been sufficiently studied for the pregnancy process. While PCT is expressed at a very low level in normal pregnancy, the increase in PCT level is associated with an inflammatory condition. Whether PCT can be accepted as a marker of PE, a pregnancy disease characterized by systemic inflammation, is being investigated and is still up to date [17].

PE, which is characterized by hypertension and proteinuria, is becoming an increasingly common diagnosis health problem worldwide [18]. In this context, we aimed to determine the potential of vitamin $\mathrm{D}$ deficiency and the imbalance caused by some pro-inflammatory markers and angiogenic factors in the placental-centered circulation to cause maternal syndrome in PE and also the role of such biochemical parameters in the prediction of PE.

\section{Materials ve Methods}

\subsection{Patients and study design}

In our prospective study, we investigated 31 pregnant women diagnosed with PE with a single live fetus at 24 or more weeks of gestation and 32 normotensive healthy pregnant women without any systemic disease in accordance with the gestational weeks and demographic characteristics of the PE group as the control group. Pregnant women with any systemic disease, multiple pregnancies with hematological disease and GDM (Gestational Diabetes Mellitus) type 1 and type 2 diagnoses with chronic inflammation and above 40 years of age with spot urine analysis findings were not included in the study. The Medical Ethics Committee of the 
University of Sakarya approved the study (reference number: E.4245) on April 04, 2019, which conformed to the tenets of the Declaration of Helsinki. Each awake and conscious participant signed the Informed Consent Form approved by the Ethics Committee of the University Hospital Sakarya.

\subsection{Whole blood analysis}

The blood samples were obtained from the patients and control group into the biochemistry tubes and the blood samples was measured by fully automatic Cell DYN 3700 (Disera, Turkey) blood counting device and aspartate transaminase (AST) and alanine transaminase (ALT) measurement was performed on the AU5800 Biochemistry System (Beckman Coulter, USA). The blood samples taken from individuals were centrifuged at $1500 \mathrm{x} \mathrm{g}$ for 10 minutes at room temperature $\left(24^{\circ} \mathrm{C}\right)$ and their serum and plasma were separated, and other further analysis were performed.

\subsection{Vitamin D analysis}

Vitamin D level was measured by CLIA (chemiluminescence immunoassays) method in ADVIA Centaur XPT (Siemens Healthcare Diagnostics, Germany) auto analyzer using ADVIA Centaur Vitamin D kit (Siemens Healthcare Diagnostics, Germany). The CLIA method is an antibody competitive immunoassay using an antifluorescent monoclonal mouse antibody covalently linked to acridinium ester labeled (AE) anti-25 (OH) Vitamin D monoclonal mouse antibody and fluorescently labeled vitamin $\mathrm{D}$ analogue paramagnetic particles (PMP).

\subsection{TNF- $\alpha$ analysis}

TNF- $\alpha$ level was measured by ELISA (EnzymeLinked Immunosorbent Assay) method using the TNF- $\alpha$ ELISA kit (DIAsource, Belgium). Absorbance was read at $450 \mathrm{~nm}$ at the end of the analysis. TNF- $\alpha$ concentrations in the samples were calculated as $\mathrm{pg} / \mathrm{mL}$ using the calibration curve drawn with the absorbance values of the standards.

\subsection{PLGF analysis}

PLGF level was measured by ELISA (EnzymeLinked Immunosorbent Assay) method using the PLGF ELISA kit (Cloud-Clone Corp, USA). Absorbances were read at $450 \mathrm{~nm}$ at the end of the analysis. PLGF concentrations in the samples were calculated as $\mathrm{pg} / \mathrm{mL}$ using the calibration curve drawn with the absorbance values of the standards.

\subsection{PCT Analysis}

Procalcitonin (PCT) measurement was performed on the cobas E-411 (Roche, Germany) analyzer using the Elecsys BRAHMS PCT kit (Roche, Germany) using the electrochemiluminescence immunoassay (ECLIA) method.

\subsection{Statistical analysis}

All statistical analysis was assessed with "GraphPad Prism 6.0 software" and "EasyROC: a web-tool for ROC curve analysis (ver. 1.3)" was used for ROC analysis. Whether the groups were suitable for normal distribution was evaluated with the Kolmogorov-Smirnov test. Student's t test was used for comparison of the groups with normal distribution and the Mann Whitney U test was used for comparison of the groups did not show normal distribution. ROC curves were created in the PE group and the area under the curve (AUC) was calculated for each marker. $\mathrm{p}<0.05$ was considered significant. Results are given as mean \pm standard deviation (SD).

\section{Results and Discussion}

\subsection{Results}

The study was conducted between May 2019 December 2019 with a total of 63 cases, 32 of which PE patient group and 31 of them control group. We collected basic demographic parameters such as maternal age and gestational week $(\mathrm{GW})$ and biochemical parameters from the PE and control group. Laboratory parameters included hemoglobin (HB), hematocrit (HCT), platelet (PLT), lymphocyte (LYM), white blood cell (WBC), AST and ALT levels were evaluated for the statistical differences in PE compared with the control group (Table 1).

Table 1. Comparison of demographic features and biochemical parameters in PE and control group

\begin{tabular}{|c|c|c|}
\hline & $\begin{array}{c}\text { Control Group } \\
(n=32), A M \pm \\
\text { SD }\end{array}$ & $\begin{array}{c}\text { PE Group } \\
(\mathbf{n}=31), \\
\mathrm{AM} \pm \mathbf{S D}\end{array}$ \\
\hline Maternal age & $29,69 \pm 5,14$ & $\begin{array}{c}27,90 \pm \\
6,24^{\mathrm{d}}\end{array}$ \\
\hline Gestational week & $35,87 \pm 4,07$ & $\begin{array}{c}32,00 \pm \\
4,21^{a}\end{array}$ \\
\hline HB (g/dl) & $11,56 \pm 1,19$ & $\begin{array}{c}10,93 \pm \\
1,60^{\mathrm{d}}\end{array}$ \\
\hline HCT (\%) & $35,22 \pm 3,57$ & $\begin{array}{c}33,30 \pm \\
4,60^{\mathrm{d}}\end{array}$ \\
\hline PLT $(K / \mu L)$ & $232,91 \pm 54,18$ & $\begin{array}{c}223,06 \pm \\
61,08^{\mathrm{d}}\end{array}$ \\
\hline 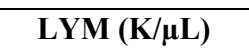 & $1,99 \pm 0,70$ & $2,59 \pm 0,88^{b}$ \\
\hline $\mathrm{WBC}(\mathrm{K} / \mu \mathrm{L})$ & $10,607 \pm 3,86$ & $\begin{array}{c}12,12 \pm \\
3,99^{\mathrm{d}}\end{array}$ \\
\hline AST (U/L) & $13,84 \pm 4,22$ & $\begin{array}{c}18,32 \pm \\
8,03^{c}\end{array}$ \\
\hline $\operatorname{ALT}(\mathbf{U} / \mathbf{L})$ & $17,53 \pm 6,76$ & $\begin{array}{c}23,58 \pm \\
10,75^{c}\end{array}$ \\
\hline
\end{tabular}

*HB: Hemoglobin, HCT: Hematocrit, PLT: Platelet, LYM: Lymphocyte, WBC: White blood cell, AST: Aspartate transaminase, ALT: Alanine transaminase, AM: Arithmetic mean, SD: Standard deviation, n: number of individuals, a: There is a significant difference compared to the control group; $\mathrm{p}<0.001$, ${ }^{\mathrm{b}}$ : There is a significant difference compared to the control group; $\mathrm{p}<0.01,{ }^{\mathrm{c}}$ : There is a significant difference compared to the control group; $\mathrm{p}<0.05,{ }^{\mathrm{d}}$ : There is not a significant difference compared to the control group; $\mathrm{p}>0.05$. 
Additionally, statistical evaluation showed that there is a significant difference in GW, LYM, AST and ALT parameters $(\mathrm{p}<0.001, \mathrm{p}<0.01$ and $\mathrm{p}<0.05)$. Nevertheless, there was no statistically significant difference for maternal age, HB, HCT, PLT and WBC between PE and control groups (Table 1).

According to the results of biochemical parameter analysis, the LYM, AST and ALT level was found significantly higher in PE group $(2.59 \pm 0.88$, $18.32 \pm 8.03$ and $23.58 \pm 10.75)$ than control group $(1.99 \pm 0.70, \quad 13.84 \pm 4.22$ and $17.53 \pm 6.76)$ respectively (Table 1). However, GW levels were found significantly lower in PE group (32.00 \pm 4.21$)$ than control group $(35.87 \pm 4.07)$ (Table 1). In considered these data, ROC analysis was performed to determine the roles of statistically significant parameters (GW, LYM, AST and ALT) in the prediction of PE (Table 3). According to the ROC analysis results the area under the ROC curve obtained for GW, LYM, AST and ALT values were $0.814,0.681,0.639$ and 0.663 , respectively (for $95 \%$ confidence interval). Consequently, we thought that GW values are could be used in the prediction of patients with the potential of developed PE (Figure 1A).

The results of Vitamin D, TNF- $\alpha$, PLGF and PCT parameter analysis showed that, Vitamin $\mathrm{D}$ and PLGF levels were found significantly lower in PE group (10.93 \pm 4.74 and $127.37 \pm 27.15)$ than control group (15.95 \pm 6.62 and $179.32 \pm 36.25)$, respectively (Table 2). However, TNF- $\alpha$ and PCT levels were found higher in PE group (102.82 \pm 85.34 and $.219 \pm 0.058)$ than control group $(35.70 \pm 38.00$ and $0.188 \pm 0.027$ ), respectively (Table 2 ).
(A)

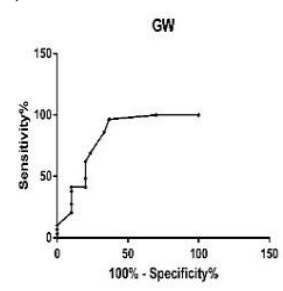

(C)

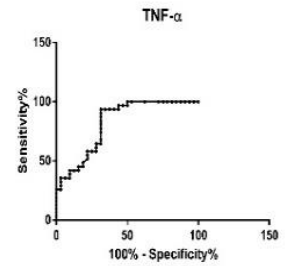

(B)

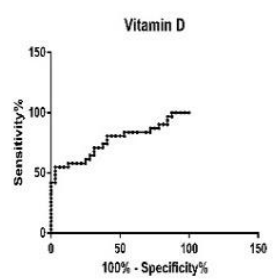

(D)

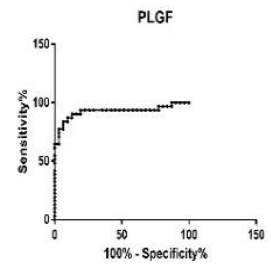

Figure 1. ROC curves obtained for (A) GW, (B) Vitamin D, (C) PLGF and (D) TNF- $\alpha$ in the prediction of PE.

Additionally, ROC analysis was performed to determine the roles of statistically significant parameters (Vitamin D, TNF- $\alpha$, PLGF and PCT) in the prediction of PE (Table 4). According to the ROC analysis results the area under the ROC curve obtained for Vitamin D, TNF- $\alpha$, PLGF and PCT values were $0.7681,0.8201,0.9251$ and 0.6442 , respectively (for $95 \%$ confidence interval). Consequently, we thought that Vitamin D, TNF- $\alpha$, and PLGF values could be used in the prediction of patients with the potential of developed PE (Figure 1B, Figure 1C and Figure 1D).

Table 2. Comparison of Vitamin D, TNF- $\alpha$, PLGF and PCT parameters in PE and control group

\begin{tabular}{|c|c|c|c|c|}
\hline & $\begin{array}{c}\text { VitD }(\mathbf{n g} / \mathbf{m L}) \\
\text { AM } \pm \text { SD }\end{array}$ & $\begin{array}{c}\text { TNF- } \alpha(\mathbf{p g} / \mathbf{m L}) \\
\text { AM } \pm \text { SD }\end{array}$ & $\begin{array}{c}\text { PLGF }(\mathbf{p g} / \mathbf{m L}) \\
\text { AM } \pm \text { SD }\end{array}$ & $\begin{array}{c}\text { PCT }(\mathbf{n g} / \mathbf{m L}) \\
\text { AM } \pm \text { SD }\end{array}$ \\
\hline Control Group $(\mathbf{n = 3 2})$ & $15,95 \pm 6,62$ & $35,70 \pm 38,00$ & $179,32 \pm 36,25$ & $0,188 \pm 0,027$ \\
\hline $\begin{array}{c}\text { PE Group } \\
(\mathbf{n = 3 1})\end{array}$ & $\mathbf{1 0 , 9 3 \pm 4 , 7 4 ^ { a }}$ & $\mathbf{1 0 2 , 8 2 \pm 8 5 , 3 4 ^ { a }}$ & $\mathbf{1 2 7 , 3 7 \pm 2 7 , 1 5 ^ { a }}$ & $\mathbf{0 , 2 1 9 \pm 0 , 0 5 8 ^ { b }}$ \\
\hline
\end{tabular}

*TNF- $\alpha$ : Tumor necrosis factor-alpha, PLGF: Placental growth factor, PCT: Procalcitonin, ng/mL: nanogram/milliliter, pg/mL: picogram/milliliter, AM: Arithmetic mean, SD: Standard deviation, n: number of individuals, ${ }^{\text {a: }}$ There is a significant difference compared to the control group; $\mathrm{p}<0.001,{ }^{\mathrm{b}}$ : There is a significant difference compared to the control group; $\mathrm{p}<0.05$.

Table 3. ROC curve data of GW, LYM, AST and ALT parameters

\begin{tabular}{|c|c|c|c|c|c|}
\hline \multirow{2}{*}{} & \multicolumn{5}{|c|}{ Area under the ROC curve } \\
\cline { 2 - 6 } & Area (AUC) & Std. Error & P value & \multicolumn{2}{c|}{ 95\% confidence interval } \\
\cline { 2 - 6 } & & & & Upper limit & Lower limit \\
\hline GW & $\mathbf{0 , 8 1 4}$ & 0,057 & 0,0001 & 0,930 & 0,710 \\
\hline LYM & 0,681 & 0,069 & 0,015 & 0,453 & 0,202 \\
\hline AST & 0,639 & 0,071 & 0,029 & 0,504 & 0,217 \\
\hline ALT & 0,663 & 0,072 & 0,063 & 0,479 & 0,199 \\
\hline
\end{tabular}


Table 4. ROC curve data of Vitamin D, PLGF, TNF- $\alpha$ and PCT parameters

\begin{tabular}{|c|c|c|c|c|c|}
\hline \multirow{2}{*}{} & \multicolumn{5}{|c|}{ Area under the ROC curve } \\
\cline { 2 - 6 } & \multirow{2}{*}{ Area (AUC) } & \multirow{2}{*}{ Std. Error } & \multirow{2}{*}{ P value } & \multicolumn{2}{|c|}{ 95\% confidence interval } \\
\cline { 4 - 6 } & & & & Upper limit & Lower limit \\
\hline Vitamin D & $\mathbf{0 , 7 6 8 1}$ & 0,06099 & 0,0002578 & 0,8877 & 0,6486 \\
\hline TNF- $\alpha$ & $\mathbf{0 , 8 2 0 1}$ & 0,05292 & $<0,0001$ & 0,9238 & 0,7163 \\
\hline PLGF & $\mathbf{0 , 9 2 5 1}$ & 0,03853 & $<0,0001$ & 1,001 & 0,8496 \\
\hline PCT & 0,6442 & 0,07215 & 0,04936 & 0,7856 & 0,5027 \\
\hline
\end{tabular}

*TNF- $\alpha$ : Tumor necrosis factor-alpha, PLGF: Placental growth factor, PCT: Procalcitonin

\subsection{Discussion}

In our study, for the first time, we compared the determine the potential of vitamin $\mathrm{D}$ values and the imbalance caused by some pro-inflammatory markers and angiogenic factors to cause maternal syndrome in PE and also the role of such biochemical parameters in the prediction of $\mathrm{PE}$.

The pathogenesis of preeclampsia includes conditions that may be directly or indirectly affected by vitamin D, including immune dysfunction, placental implantation, abnormal angiogenesis, excessive inflammation, and hypertension. Furthermore, recent studies have shown that vitamin $\mathrm{D}$ deficiency during pregnancy has negative effects on maternal, new-born and infant health [19, 20]. Chen et al. [21] reported that serum Vitamin D levels in preeclamptic pregnant women were lower than the control group, consistent with our results. On the other hand, increasing TNF- $\alpha$ levels play an important role in the pathogenesis of preeclampsia. Consistent with our results, it was stated in the literature that the level of TNF- $\alpha$ increased significantly in preeclamptic pregnant women compared to the control group, and antiinflammatory agents could play a role in the treatment of PE [16, 22]. It has been determined that PLGF levels decrease before the onset of the syndrome in pregnant women diagnosed with preeclampsia. Consistent with our results, the PLGF level in preeclamptic pregnant women was found to be significantly lower than normotensive pregnant women in some studies in the literature [23, 24].

Systemic increase of local and pro-inflammatory cytokines in PE increases the production of PCT in macrophages, which leads to an increase in the proinflammatory cytokine production of PCT by macrophages [25]. In a study in which the PCT level was found to be significantly higher in the preeclamptic pregnant group, it was reported that high PCT levels correlated with the severity of PE [26]. Consistent with our results, PCT levels were statistically significantly higher in the PE group compared to the control group. In a study evaluating the biochemical parameters in the serum of preeclamptic pregnant women, it was reported that pregnant women with preeclampsia had statistically significantly higher AST, ALT, LDH and total cholesterol values compared to healthy pregnant women [27]. Similarly, our results revealed that the AST and
ALT values of PE group were statistically significantly higher than healthy pregnant women. In addition, according to the data we obtained from our study, a significant positive correlation was found between AST, ALT and TNF- $\alpha$ level. The ROC analysis of our study showed the Vitamin D value of $10.93 \mathrm{ng} / \mathrm{mL}$ or higher, with the sensitivity of $58.1 \%$, specificity of $75,0 \%$, a TNF- $\alpha$ value of $102,82(\mathrm{pg} / \mathrm{mL})$ or higher, with the sensitivity of $35.48 \%$, specificity of $93.75 \%$, a PLGF value of $127.37(\mathrm{pg} / \mathrm{mL})$ or higher, with the sensitivity of $51.61 \%$, specificity of $100.0 \%$, and also a GW value of 32,0 (week) or higher, with the sensitivity of $41.38 \%$, specificity of $80.0 \%$ could be used to predict PE. Therefore, for the diagnosis of PE these markers that can be used routinely and reduce the cost are needed and considering our data the use of these markers in clinical practice seems adequate [28, 29].

\section{Conclusion}

Consequently, the most important result obtained from our study is that the results for Vitamin D, TNF-a, PLGF values are consistent with the literature and they could be important markers in the prediction of PE. Our data revealed that these markers, which are already routinely analyzed, do not require an additional cost and time, pregnant women who may be at risk in terms of PE could be identified and followed up closely. Thus, maternal and fetal complications caused by preeclampsia could be reduced. However, we think that our results should be supported by larger studies and that patients with different hematological and biochemical results should be evaluated in terms of PE.

\section{Acknowledgment}

This study was supported by the Scientific Research Projects Foundation (BAP) of the Sakarya University of Turkey [Projects No: 2019-7-24-117].

\section{References}

1. Agarwai, I, Karumanchi, S.A, Preeclampsia and anti-angiogenic state, Pregnancy Hypertension, 2011, 1(1), 17-21.

2. Aggarwal, R, Jain, A.K, Mittal, P, Kohli, M, Jawanjal, P, Rath, G, Association of pro-and anti-inflammatory cytokines in preeclampsia, Journal of clinical laboratory analysis., 2019, 33(4), e22834.

3. Tahergorabi, Z, Khazaei, M, A review on angiogenesis and its assays, Iran Journal of Basic Medical Science, 2012, 15(6), 1110-1126.

4. Tomimatsu, T, Mimura, K, Matsuzaki, S, Endo, M, Kumasawa, K, Kimura T, Preeclampsia: maternal systemic vascular disorder caused 
by generalized endothelial dysfunction due to placental antiangiogenic factors, International Journal of Molecular Science 2019, 20(17), 4246.

5. Collier, A.Y, Zsengeller, Z, Pernicone, E, Salahuddin, S, Khankin, E.V, Karumanchi, S.A, Placental sFLT1 is associated with complement activation and syncytiotrophoblast damage in preeclampsia, Hypertension in Pregnancy, 2019, 38(3), 193-199.

6. Chang, X, Yao, J, He, Q, Liu, M, Duan, T, Wang, K, Exosomes from women with preeclampsia induced vascular dysfunction by delivering sFlt (Soluble Fms-Like Tyrosine Kinase)-1 and sEng (Soluble Endoglin) to endothelial cells, Hypertension, 2018, 72(6), $1381-1390$

7. Tellioğlu, A, Başaran, S, Vitamin D in the light of current knowledge, Archive Medical Review Journal, 2013, 22(2):259-271.

8. Neumaier, M, Braun, A, Wagener, C, Fundamentals of quality assessment of molecular amplification methods in clinical diagnostics. International Federation of Clinical Chemistry Scientific Division Committee on Molecular Biology Techniques, Clinical chemistry, 1998, 44(1), 12-26.

9. Obi, Y, Hamano, T, Isaka, Y, Prevalence and prognostic implications of vitamin D deficiency in chronic kidney disease, Disease Markers, 2015, 1-9.

10. Erbay, E, Mersin, S, İbrahimoğlu, Ö, Vitamin D and its effect on body systems, Journal of Health Scholars, 2019, 6(3), 201-206.

11. Walentowicz-Sadlecka, M, Domaracki, P, Sadlecki, P, Siodmiak, J, Grabiec, M, Walentowicz, P, Moliz, M.T.A, Odrowaz-Sypniewska $\mathrm{G}$, Assesment of the sFlt-1 and sFlt-1/25(OH)D ratio as a diagnostic tool in gestational hypertension $(\mathrm{GH})$, preeclampsia (PE), and gestational diabetes mellitus (GDM), Disease Markers, 2019, 5870239.

12. Li, Y, Lin, Y, Tumor necrosis factor alpha-308G/A polymorphism and the risk of multiple myeloma: a meta- analysis of pooled data from twelve case- control studies, Turkish Journal of Hematology, 2019, 36(2), 72-80

13. Decout, B, Lahiri, K.D, Sabbagh M.N, Targeting tumor necrosis factor alpha for alzheimer's disease, Current Alzheimer Research, 2017, 14(4), 412-425.

14. Aydın, V, Akıcı, A, Infections due to TNF-alpha inhibitor use in rheumatological diseases, The Journal of Turkish Family Physician, 2018, 9(1), 13-24.

15. Yockey, L.J, Iwasaki, A, Role of interferons and cytokines in pregnancy and fetal development, Immunity, 2018, 49(3), 397-412.

16. Mawardi, S, Ganie, R.A, Lumbanraja, S.N, Levels of interleukın-6 and tumor necrosis factor alpha in pregnant patients with preeclampsia and patients with normal pregnancy, Indonesian $J$ of Clinical Pathology and Medical Laboratory, 2019, 25(2), 199-201.

17. Mangogna, A, Agostinis, C, Ricci, G, Romano, F, Bulla, R, Overview of procalcitonin in pregnancy and in pre-eclampsia, Clinical and experimental immunology, 2019, 198(1), 37-46.

18. Poon, L, Sahota, D, Screening and prevention of preeclampsia, Maternal-Fetal Medicine, 2019, 1(1), 25-30.

19. Bodnar, L.M, Catov, J.M, Simnah, H.N, Holick, M.F, Powers, R.W, Roberts, J.M, Maternal vitamin D deficiency increases the risk of preeclampsia, The Journal of Clinical Endocrinology and Metabolism, 2007, 92(9), 3517-3522.

20. Evans, K.N, Bulmer, J.N, Kilby, M.D, Hewison, M, Vitamin D and placental decidual function, Journal of the Society for Gynecologic Investigation, 2004, 11, 263-271

21. Chen, X, Xi, X, Cui, F, Wen, M, Hong, A, Hu, Z, Ni, J, Abnormal expression and clinical significance of 25 - hydroxyvitamin D and sFlt-1 in patients with preeclampsia, Journal of International Medical Research, 2019, 47(10), 4673-4682.

22. Udenze, I, Amadi, C, Awolola, N, Makwe, C.C, The role of cytokines as inflammatory mediators in preeclampsia, The Pan African Medical Journal, 2015, 20, 219.

23. Chau, K, Hennessy, A, Makris, A, Placental growth factor and preeclampsia, Journal of Human Hypertension, 2017, 31(12): 782-786.

24. Shokry, M, Bedaiwy, M.A, Fathalla, M.M, Alsemary, A, Elwakil, S Murphy, A, Maternal serum placental growth factor and soluble fmslike tyrosine kinase 1 as early predictors of preeclampsia, Acta Obstetricia et Gynecologica Scandinavica, 2010, 89(1), 143-6.

25. Mangogna, A, Agostinis, C, Ricci, G, Romano, F, Bulla, R, Overview of procalcitonin in pregnancy and in pre-eclampsia, Clinical and Experimental Immunology, 2019, 198, 37-46.

26. Ülkumen, B.A, Güvenç, Y, Göker, A, Gözükara C, The relationship between neutrophil gelatinase-associated lipocalin (NGAL) and procalcitonin levels with the presence and severity of preeclampsia, The Journal of Maternal-Fetal \& Neonatal Medicine, 2015, 28(16), 895-90.

27. Dacaj, R, Izetbegovic, S, Stojkanvic, G, Dreshaj, S, Elevated liver enzymes in cases of preeclampsia and intrauterine growth restriction, Medical Archives, 2016, 70(1), 44-47.

28. Gezer, C, Ekin, A, Ertas, I.E, Ozeren, M, Solmaz, U, Mat, E, Taner, C.E, High first-trimester neutrophil-to-lymphocyte and platelet-tolymphocyte ratios are indicators for early diagnosis of preeclampsia, Ginekologia Polska, 2016, 87(6), 431-5.

29. Hajian-Tilaki, K, Receiver operating characteristic (ROC) curve analysis for medical diagnostic test evaluation, Caspian Journal of Internal Medicine, 2013, 4(2), 627-635.

http://edergi.cbu.edu.tr/ojs/index.php/cbusbed isimli yazarın CBU-SBED başlıklı eseri bu Creative Commons Alıntı-Gayriticari4.0 Uluslararası Lisansı ile lisanslanmıştır.

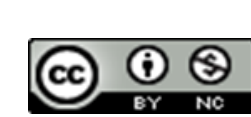

